DOI: https://doi.org/10.24127/ajpm.v8i1.1951

\title{
PENGEMBANGAN MEDIA PEMBELAJARAN POP-UP BOOK BERBASIS AUDIO PADA MATERI BANGUN DATAR SEGIEMPAT DI SMP
}

\author{
Baiduri $^{1 *}$, Marhan Taufik ${ }^{2}$, Lufita Elfiani ${ }^{3}$ \\ 1, 2, 3 Pendidikan Matematika, Universitas Muhammadiyah Malang \\ ${ }^{*}$ Corresponding author. Address: Department of Mathematics Education, Muhammadiyah University of Malang, \\ 65143, Malang, Indonesia \\ E-mail: baiduriumm@gmail.com $\left.{ }^{1 *}\right)$ \\ marhan@umm.ac.id ${ }^{2}$ \\ lufitaelfiani65@gmail.com ${ }^{3)}$
}

Received 26 April 2019; Received in revised form 3 May 2019; Accepted 8 May 2019

\begin{abstract}
This study aimed to develop the learning media and investigated the effectiveness of audio-based Pop-Up Book media on the two-dimensional rectangular shape. This media was tested twice in a small group of 6 students and in a large group of 25 students. Respondents were the $7^{\text {th }}$ grade students. The result of expert validation showed the average percentage of $88,16 \%$ and was considered valid, thus the learning media was allowed to be used and tested. The analysis of effectiveness in small and large groups in a row revealed that students' respond was very good, with the percentage of $88.1 \%$ and $88.87 \%$. In addition, the activities of students in the class were very good, showed by the percentage of $92 \%$ and $86.8 \%$. Finally, the classical completeness of the learning outcomes obtained the percentage of $100 \%$ from 6 students and 92\% from 23 students who completed the test. Therefore, it can be concluded that the application of audio-based Pop-Up Book on the two-dimensional rectangular shape was effective for Junior High School students.
\end{abstract}

Keywords: Audio; 2D Rectangular; Learning media; Pop-Up.

\section{PENDAHULUAN}

Matematika merupakan salah satu pelajaran yang sangat berperan penting dalam perkembangan ilmu pengetahuan. Matematika terdapat pada jenjang sekolah dasar (SD) sampai dengan jenjang perguruan tinggi (PT). Indonesia pada tahun 2015 Programme for International Students Assessment (PISA) melaporkan bahwa Indonesia menduduki peringkat 63 dari 70 negara untuk matematika dengan skor 386. PISA manyatakan bahwa Indonesia masih tergolong rendah dalam penguasaan materi. Saat ini minat siswa pada pelajaran matematika masih kurang, faktornya adalah karena jam pelajaran yang lama, rumus yang banyak, dan sulit untuk dimengerti, bagi siswa rumus pada matematika abstrak dan susah untuk dipecahkan (Pamuji,
Budiyono \& Yuzianah, 2014). Siswa yang menganggap matematika sebagai pelajaran yang relatif sulit dan membentuk kesan dan pengalaman secara negatif terhadap matematika umumnya berdampak kurang baik bagi motivasi belajar matematika (Gurganus, 2010).

Ini berarti perlu adanya pengembangan proses pembelajaran matematika dengan memanfaatkan perkembangan teknologi yang ada, yaitu menyajikan sebuah media pembelajaran matematika untuk membantu siswa mempermudah memahami konsep, memecahkan masalah dan dapat mempermudah tercapainya tujuan pembelajaran matematika. Media pembelajaran merupakan wadah untuk menyampaikan pesan pembelajaran, agar tujuan 
DOI: https://doi.org/10.24127/ajpm.v8i1.1951

pembelajaran dapat tercapai. Penggunaan media secara kreatif dapat memperbesar kemungkinan bagi siswa untuk belajar lebih banyak, mengingat dengan baik (Riyana, 2012). Media pembelajaran dapat memvisualisasikan materi matematika yang cenderung abstrak (Widodo \& Wahyudi, 2018). Media pembelajaran digunakan untuk memudahkan komunikasi dalam proses belajar mengajar, diupayakan secara optimal untuk dapat menumbuhkan kreativitas dan motivasi dalam kegiatan belajar untuk meningkatkan kualitas pendidikan (Wiana, 2017).

Media pembelajaran pada setiap tahunnya mengalami perkembangan. Salah satu jenis media pembelajaran yang bisa membuat siswa tertarik, tidak bosan, dan membantu siswa saat proses pembelajaran yaitu media Pop-Up. Pop$U p$ sangat mengagumkan jika digunakan pada kegiatan pembelajaran berbentuk media visual. Media visual Pop-Up dapat memberi visualisasi cerita yang sangat menarik, karena gambar yang disajikan dapat bergerak pada setiap bagian yang dibuka maupun digeser, serta tampilannya yang berbentuk dua dan tiga dimensi (Widalatika, 2014). Pop-Up berisi potongan-potongan kertas yang muncul atau bergerak ketika dibuka dan sepenuhnya dilipat ketika buku ditutup, serta tampilan yang berbentuk dua atau tiga dimensi (Ahmadi, Fakhruddin, Trimurtini \& Khasanah, 2017). Media Pop-Up adalah selembar kertas yang dilipat dimana struktur dua dimensi atau tiga dimensi muncul ketika dibuka (Okamura \& Igarashi, 2010)

Beberapa penelitian yang relevan dengan pengembangan Pop-Up Book sebagai media pembelajaran matematika adalah Kharisma (2017) mengembangkan media pembelajaran Pop-Up untuk meningkatkan hasil belajar siswa pada materi minyak bumi dan petrokimia. Dewanti (2018) mengembangkan media Pop-Up Book untuk pembelajaran lingkungan tempat tinggalku. Devi \& Maisaroh (2017) mengembangkan buku Pop-Up wayang tokoh pandhawa. Azizan (2017) mengembangkan Pop-Up Book dalam pembelajaran menulis puisi berbasis psychowriting. Vate (2012) mengembangkan media Pop-Up Book 3D Augmented Reality Multimedia pada pelajaran bahasa inggris. Keempat penelitian yang relavan ini mengembangkan media Pop-Up Book sebagai media pembelajaran.

Pengembangan media pembelajaran Pop-Up yang dikembangkan kali ini, ditambahkan audio agar lebih menarik dan lebih interaktif, serta siswa lebih bersemangat ketika pembelajaran berlangsung. Informasi yang disajikan akan memberikan kesan mendalam dan lebih lama tersimpan pada diri siswa serta dapat memperbesar perhatian setiap siswa. Melalui media audio-visual, konten pembelajaran bisa lebih interaktif dan memungkinkan lalu lintas dua arah dalam proses pembelajaran (Haryoko, 2012). Media audio-visual diam merupakan media yang penyampaian pesannya dapat diterima oleh pendengaran dan penglihatan, tetapi gambar yang disajikan diam atau sedikit gerak (Susilana \& Riyana, 2009). Media audio-visual merupakan penggabungan gambar dan suara untuk mengaktualisasikan atau memvisualisasikan kenyataan tertentu berdasarkan gambar (Cintas \& Remael, 2014).

Beberapa pengembangan media pop-up book sebelumnya belum dilengkapi oleh audio. Oleh karenanya perlu dikembangkan media pembelajaran Pop-Up yang lebih menarik dan lebih interaktif, serta siswa lebih bersemangat ketika pembelajaran 
DOI: https://doi.org/10.24127/ajpm.v8i1.1951

berlangsung dengan cara melengkapinya dengan audio. Sehingga informasi yang disajikan akan memberikan kesan mendalam dan lebih lama tersimpan pada diri siswa serta dapat memperbesar perhatian setiap siswa.

Melalui pengembangan media pembelajaran Pop Up berbasis audio, siswa diharapkan lebih mudah memahami pelajaran matematika dan menarik minat belajar khususnya pada materi bangun datar segiempat. Bangun datar segiempat yang dijelaskan pada media ini adalah persegi, persegi panjang, jajargenjang, trapesium, layang-layang dan belah ketupat. Dengan adanya media Pop Up berbasis audio ini diharapkan bisa membantu untuk memberikan solusi yang berkaitan dengan bangun datar segiempat. Materi segiempat (persegi panjang, persegi, jajargenjang, belahketupat, layang-layang, dan trapesium) sangat penting untuk dikuasai siswa kelas VII karena menjadi materi prasyarat saat siswa duduk di kelas VIII mempelajari bangun ruang sisi datar (Mustakim, 2016). Materi bangun datar segiempat merupakan materi prasyarat untuk mempelajari materi bangun ruang sisi datar dan kesebangunan (Rahayu, 2016).

Hubungan antara penelitian yang relevan dengan penelitian saat ini adalah menghasilkan media pembelajaran Pop-Up Book berbasis audio pada materi bangun datar segiempat. Pengembangan media PopUp Book berbasis audio dinilai berdasarkan kevalidan yang mencakup 5 aspek yaitu : 1) aspek tampilan, 2) aspek audio, 3) aspek bahasa, 4) aspek layout dan 5) aspek isi. Selain itu pengembangan media Pop-Up Book berbasis audio melihat pada respon siswa, aktivitas siswa dan hasil belajar siswa setelah menggunakan media Pop-
Up Book berbasis audio. Pengembangan media Pop-Up Book berbasis audio bertujuan untuk mendeskripsikan proses pengembangan dan keefektifan media pembelajaran Pop-Up Book berbasis audio.

Tidak semua media pembelajaran efektif digunakan pada saat kegiatan pembelajaran. Media pembelajaran dikatakan efektif apabila angket respon siswa yang baik dengan persentase $\geq$ $75 \%$, aktivitas siswa yang baik dengan persentase $\geq 75 \%$ dan hasil belajar siswa tuntas jika memperoleh nilai diatas KKM yaitu 75 dengan persentase ketuntasan klasikal $\geq 75 \%$ (Wahyuningsih, 2012). Media yang dikatakan efektif jika dapat meningkatkan ketertarikan siswa dalam belajar dan tercapainya tujuan pembelajaran (Musfiqon, 2012).

Berdasarkan pernyataan ini, maka tujuan penelitian ini adalah mendeskripsikan pengembangan media pop-up book berbasis audio yang valid dan efektif.

\section{METODE PENELITIAN}

Penelitian ini merupakan penelitian pengembangan atau $\mathrm{R} \& \mathrm{D}$ (Research and Development) dengan menggunakan model (Sugiyono, 2015) yang memiliki sepuluh tahap yaitu potensi masalah, pengumpulan informasi, desain produk, validasi desain, revisi desain, uji coba produk, revisi produk, uji coba pemakaian, revisi produk, produksi massal. Pada penelitian ini peneliti hanya melakukan sampai pada tahap ke sembilan. Penelitian ini dilaksanakan pada semester ganjil tahun ajaran 2018/2019. Uji coba dilakukan di SMP Islam Ma'arif 03 Malang dengan subjek siswa kelas VII. Uji coba dilakukan sebanyak dua kali, yaitu pertama dilakukan pada kelompok kecil sebanyak 6 siswa dan 
DOI: https://doi.org/10.24127/ajpm.v8i1.1951

kedua dilakukan pada kelompok besar kepada 25 siswa.

Prosedur penelitian yang digunakan sesuai dengan model pengembangan (Sugiyono, 2015). a) Tahap potensi masalah terkait masalah yang ditemukan disekolah mengenai penggunaan media pembelajaran yang digunakan. b) Tahap pengumpulan informasi dilakukan dengan wawancara kepada guru bidang studi matematika. c) Tahap desain produk yaitu dimulai dari penyusunan materi, penyusunan cover, box kemasan, isi Pop-Up Book, panduan penggunaan, dubbing dan pemasangan audio serta merencanakan bahan-bahan yang digunakan untuk mencetak Pop-Up Book dan pemasangan audio. d) Tahap Validasi desain yaitu memerlukan beberapa pakar atau ahli yang sudah berpengalaman untuk menilai produk yang baru dirancang, yaitu validator ahli merupakan dosen pendidikan matematika dan praktisi pembelajaran yang merupakan guru. e) Tahap revisi desain yaitu kekurangan yang diberikan oleh validator dicoba untuk dikurangi dengan cara memperbaiki desain. Tahap uji coba pruduk yaitu dilakukan pada kelompok kecil yang berjumlah 6 siswa. f) Tahap revisi produk yaitu kekurangan yang didapat pada uji coba produk berusaha diperbaiki. g) Tahap uji coba pemakaian yaitu dilakukan pada kelompok besar yang berjumlah 25 siswa. h) Tahap revisi produk yaitu jika pada uji coba yang terakhir masih terdapat kekurangan yang perlu memperbaiki.

Instrumen pengumpulan data yang digunakan yaitu angket validasi media, angket respon siswa, lembar aktivitas siswa dan lembar tes hasil belajar. Angket validasi media digunakan untuk mengukur tingkat kevalidan media. Angket respon siswa, lembar aktivitas siswa dan lembar tes hasil belajar digunakan untuk mengetahui keefektifan produk media. Berikut aspek-aspek yang akan dinilai dalam pengembangan media Pop-Up Book berbasis audio:

1. Validasi media terdiri dari 5 aspek yang setiap aspeknya memiliki indikator (Husain, 2017). a) aspek tampilan: komposisi dan tata letak pada cover seimbang, penampilan pop-up colour full, huruf yang digunakan jelas dan mudah dibaca, ilustrasi gambar dan materi mudah dipahami, kualitas gambar jelas. b) aspek audio: suara narator terdengar jelas, soal yang disampaikan mudah dipahami dan jelas. c) aspek bahasa: menggunakan bahasa indonesia yang baik dan benar, bahasa mudah dipahami oleh siswa. d) aspek layout: layout tidak monoton, layoutnya mudah untuk digunakan, ketepatan gambar dan materi. e) aspek isi : ketepatan judul dengan isi materi, uraian materi yang jelas, penyajian materi mudah dipahami, contoh soal yang diberikan jelas.

2. Respon siswa terdiri dari 3 aspek yang setiap aspeknya memiliki indikator (Cahyadi, 2014) dan (Cahyani, 2014). a) aspek isi: menggunakan bahasa yang baik dan benar, materi mudah dipahami dan jelas, contoh soal yang diberikan jelas. b) aspek tampilan: setiap halaman menarik, gambar yang disajikan jelas, tata letaknya tidak membosankan, tampilannya colour full, model tulisan menarik. c) aspek audio: suara dapat didengar dengan jelas, soal yang disampaikan mudah dipahami.

3. Aktivitas siswa terdiri dari 5 aspek yang setiap aspeknya memiliki indikator (Sardiman, 2011). a) aspek 
visual: penggunakan pop-up book, layout terlihat dengan jelas, gambar yang disajikan terlihat jelas, tertarik dengan media pembelajaran. b) aspek mendengarkan: siswa mendengarkan suara dengan jelas, mudah memahami soal yang disampaikan, mudah menggunakan audio player. c) aspek menulis: mencatat hasil yang diperoleh dalam pembelajaran, menuliskan soal yang diterima dengan benar. d) aspek menggambar: menggambarkan kembali bangun datar yang telah dipelajari, menggambarkan soal yang disampaikan melalui audio player. e) aspek emosional : senang mengikuti pembelajaran dengan media pop-up book berbasis audio, berani bertanya kepada guru. f) aspek mental: mempersiapkan diri mengikuti pembelajaran, memperhatikan arahan guru, semangat mengikuti pembelajaran.

\section{Hasil Belajar Siswa}

Tes digunakan untuk mengetahui hasil belajar siswa setelah menggunakan media pembelajaran Pop-Up Book berbasis audio. Tes berupa empat butir soal yang diberikan terpisah dari Pop-Up Book berbasis audio ini selanjutnya akan dianalisis sesuai dengan Kriteria Ketuntasan Minimal (KKM) yang digunakan di SMP Islam Ma'arif 03 Malang.

Teknik analisis data meliputi analisis kevalidan dan analisis keefektifan. Produk dikatakan valid dengan persentase $\geq 60 \%$. Analisis data kevalidan diperoleh dengan cara menghitung persentase kevalidan dengan membagi jumlah skor yang diperoleh dengan skor maksimal dari validator pada setiap aspek dan dikalikan $100 \%$. Hasil validasi yang telah diketahui persentasenya dapat dicocokkan dengan rata-rata kriteria validasi (Wirayanti \& Muksar, 2016) seperti yang disajikan pada Tabel 1 .

\begin{tabular}{cc}
\multicolumn{2}{c}{ Tabel 1. Rata-Rata Kriteria Validasi } \\
\hline Persentase & Kriteria \\
\hline $80 \leq \bar{V} \leq 100$ & Sangat Valid \\
$60 \leq \bar{V}<80$ & Valid \\
$40 \leq \bar{V}<60$ & Cukup Valid \\
$20 \leq \bar{V}<40$ & Kurang Valid \\
$0 \leq \bar{V}<20$ & Tidak Valid \\
\hline
\end{tabular}

Analisis keefektifan media diukur dari angket respon siswa yang baik dengan persentase $\geq 75 \%$, aktivitas siswa yang baik dengan persentase $\geq$ $75 \%$ dan hasil belajar siswa tuntas jika memperoleh nilai diatas KKM yaitu 75 dengan persentase ketuntasan klasikal $\geq$ $75 \%$. Analisis data angket respon dan analisis data aktivitas diperoleh dengan cara menghitung persentase jumlah skor yang diperoleh dibagi dengan skor maksimal dan dikalikan $100 \%$. Hasil dari persentase angket respon siswa dan aktivitas siswa yang telah diperoleh kemudian dicocokkan dengan rata-rata kriteria persentase menurut Arikunto (2013) pada Tabel 2.

Tabel 2. Rata-Rata Respon dan Aktivitas

\begin{tabular}{cc}
\hline Persentase & Kriteria \\
\hline $80 \leq \bar{P} \leq 100$ & Sangat Baik \\
$60 \leq \bar{P}<80$ & Baik \\
$40 \leq \bar{P}<60$ & Cukup Baik \\
$20 \leq \bar{P}<40$ & Kurang Baik \\
$0 \leq \bar{P}<20$ & Tidak Baik \\
\hline
\end{tabular}

Jadi dikatakan efektif jika memenuhi 3 syarat yaitu angket respon siswa minimum berkriteria baik, aktivitas siswa minimum berkriteria baik dan hasil belajar siswa memiliki persentase ketuntasan klasikal $\geq 75 \%$, dengan kriteria ketuntasan minimum 75 . 
DOI: https://doi.org/10.24127/ajpm.v8i1.1951

\section{HASIL PENELITIAN DAN PEMBAHASAN}

Langkah yang digunakan dalam pengembangan produk ini mengadopsi dan mengadaptasi proses pengembangan Sugiyono yang terdiri dari sembilan tahap yaitu potensi masalah, pengumpulan informasi, desain poduk, validasi desain, revisi desain, uji coba produk, revisi produk, uji coba pemakaian dan revisi produk. Kegiatan setiap tahap dalam proses pengembangan produk adalah seperti berikut:

\section{1) Potensi Masalah}

Hasil yang diperoleh selama
kegiatan
menggunakan metode ceramah dengan bantuan buku paket dan LKS. Siswa juga merasa bosan dengan kegiatan pembelajaran yang terus berulang seperti itu. Penggunaan media belajar di sekolah sangat minim sekali. Serta fasilitas seperti LCD juga masih belum tersedia disetiap kelas. Jika guru menggunakan media Power Point biasanya melihat situasi kelasnya terlebih dahulu, karena ketersediaan LCD hanya terdapat di Laboratorium saja. Sehingga berdasarkan permasalahan diatas perlu adanya media pembelajaran baru berupa Pop-Up Book Berbasis Audio bagi siswa agar siswa tidak bosan ketika kegiatan pembelajaran berlangsung. Media pembelajaran yang dikembangkan tentang sifat-sifat, luas dan keliling bangun datar segiempat.

2) Pengumpulan Informasi

Informasi dikumpulkan melalui observasi dan wawancara secara langsung ke sekolah. Penelitian pendahuluan ini meliputi observasi pada saat kegiatan pembelajaran berlangsung dan mewawancarai siswa serta guru matematika terkait media yang digunakan selama pembelajaran pembelajaran matematika. Media yang dikembangkan harus sesuai dengan Kompetensi Dasar (KD) dan indikator yang telah dirumuskan. Merumuskan Kompetensi Dasar (KD) yaitu memahami sifat-sifat bangun datar dan menggunakannya untuk menentukan keliling dan luas, menyelesaikan permasalahan nyata yang terkait penerapan sifat-sifat persegi panjang, persegi, trapesium, jajargenjang, belah ketupat, dan layang-layang. Merumuskan Indikator yaitu mengetahui macammacam bangun datar segiempat dan sifat-sifatnya, menyelesaikan permasalahan yang terkait bangun datar segiempat.

3) Desain Produk

Tahap desain produk perlu bantuan software Corel Draw X7. Program ini digunakan untuk mendesain Pop-Up Book sebelum nantinya dicetak. Desain produk disajikan pada Tabel 1-4.

a) Penyusunan Materi yaitu bangun datar segiempat menggunakan buku Matematika SMP/MTS kelas VII semester 2 kurikulum 2013 edisi revisi 2017.

b) Penyusunan Cover yaitu sampul depan dan belakang dibuat dilembar kerja software Corel Draw X7 dengan ukuran A3. Kertas yang digunakan untuk mencetak yaitu Art Paper dengan ketebalan 150 gram dengan ukuran A2. Jadi desain sampul diletakkan ditengah-tengah kertas A2 agar mempunyai sisa dibagian atas bawah dan kanan kiri. Setelah dicetak, pada sisi belakang bagian tengah ditempel kertas karton ukuran A3 dengan ketebalan 4,3 $\mathrm{mm}$ lalu sisa kertas bagian atas bawah dan kanan kiri juga ditempel dikertas karton. 


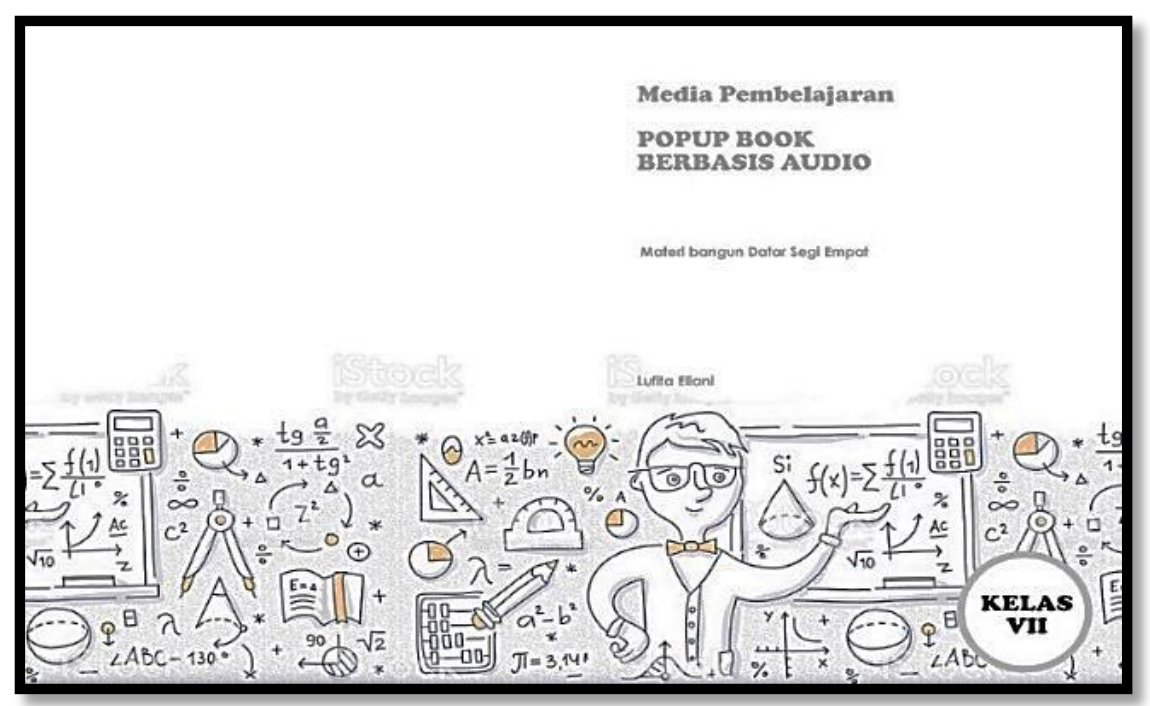

Gambar 1. Tampilan Cover

c) Penyusunan Box Kemasan yaitu box kemasan dibuat dilembar kerja software Corel Draw $X 7$ dengan ukuran $61 \mathrm{~cm} \times 54 \mathrm{~cm}$. Dicetak dengan menggunakan kertas Art Paper dengan ketebalan 310 gram ukuran $70 \mathrm{~cm} \times 60 \mathrm{~cm}$.

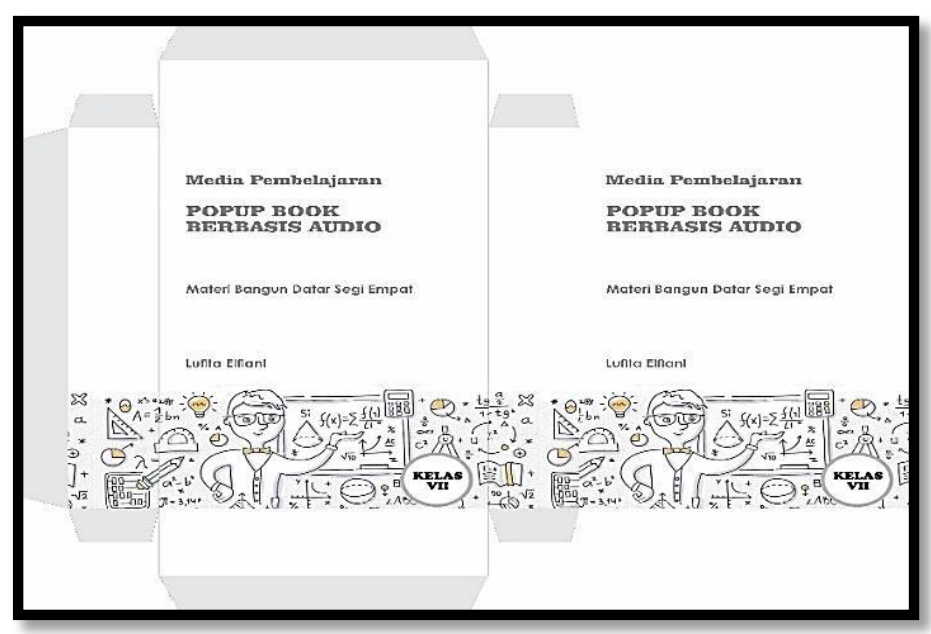

Gambar 2. Tampilan Kemasan

d) Penyusunan Isi Pop-Up Book yaitu isi Pop-Up Book dibuat dilembar kerja software Corel Draw X7 dengan ukuran A3. Pada bagian isi terdapat $\mathrm{KD}$, indikator, daftar isi, audio, sifat-sifat bangun datar segiempat, rumus luas dan keliling bangun datar segiempat, contoh bangun datar segiempat dan contoh soal bangun datar segi empat. Dicetak menggunakan kertas Art Paper dengan ketebalan 310 gram. 
DOI: https://doi.org/10.24127/ajpm.v8i1.1951

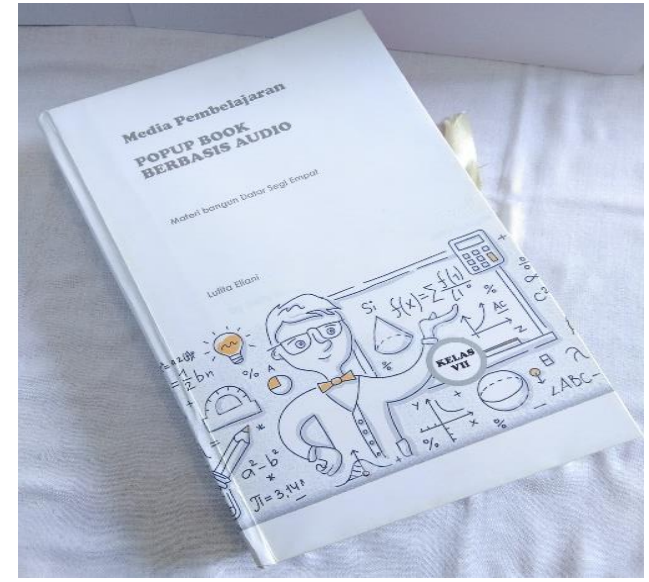

Ketika Buku Belum Terbuka

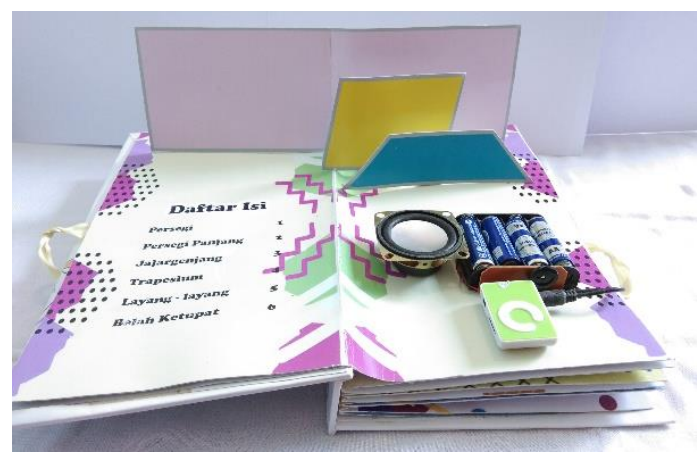

Halaman Kedua Berisi Daftar Isi dan Audio Soal

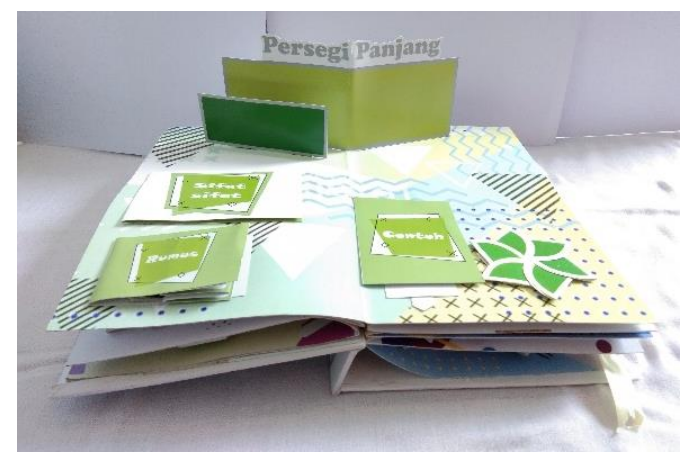

Halaman Keempat Tentang Persegi Panjang

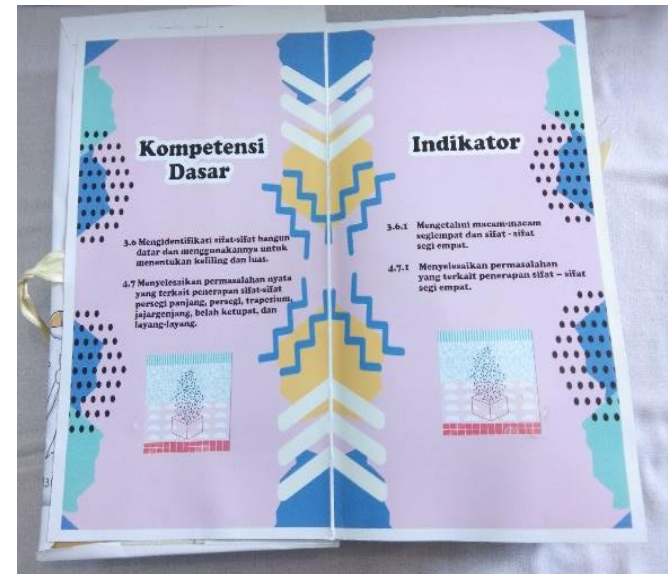

Halaman Pertama Berisi KI dan KD

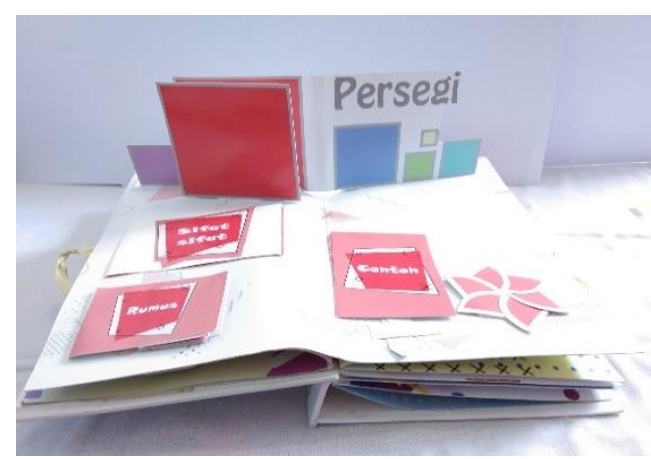

Halaman Ketiga Tentang Persegi

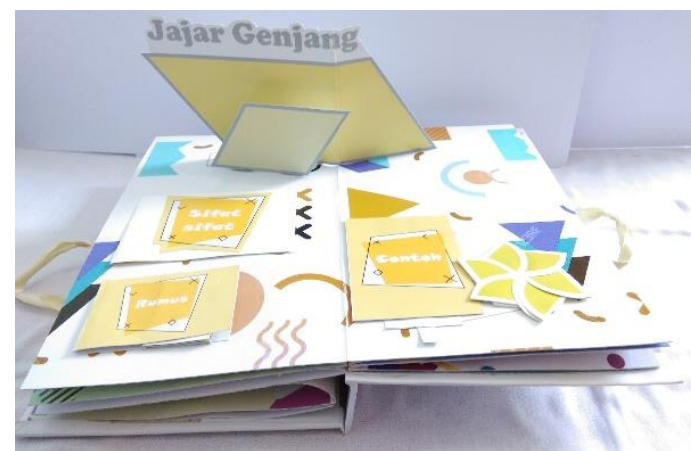

Halaman Kelima Tentang Jajargenjang 
DOI: https://doi.org/10.24127/ajpm.v8i1.1951

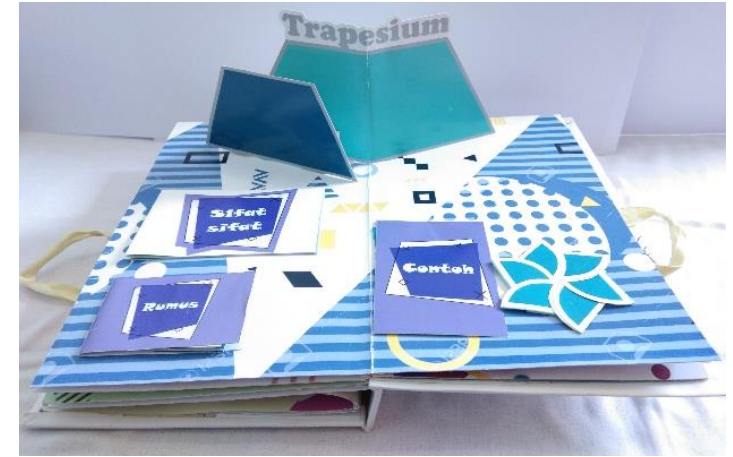

Halaman Keenam Tentang Trapesium

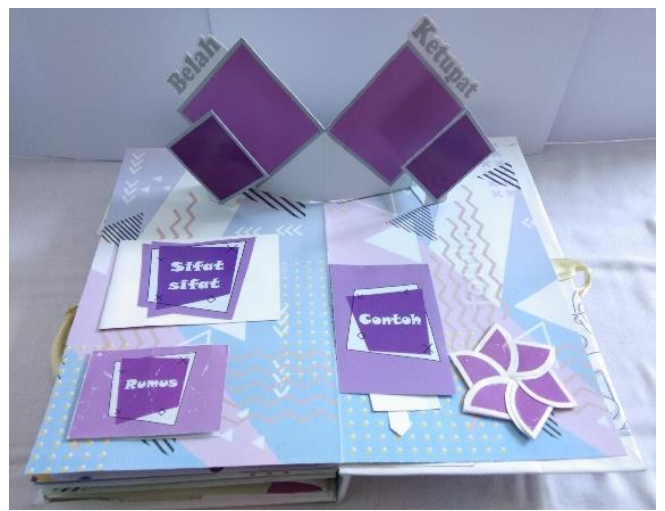

Halaman Kedelepan Tentang Belah Ketupat

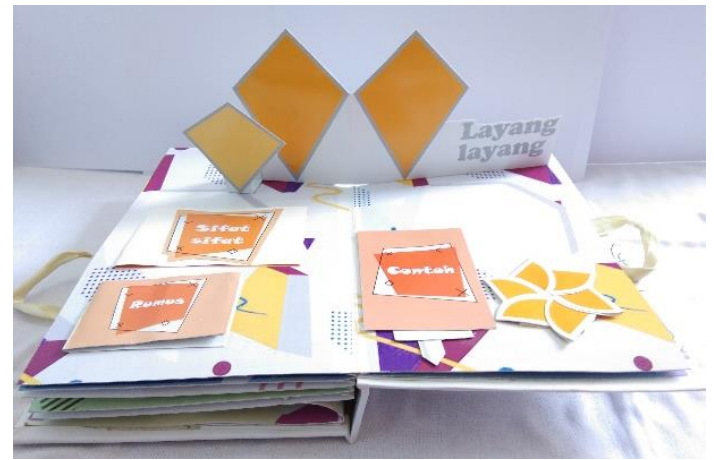

Halaman Ketujuh Tentang LayangLayang

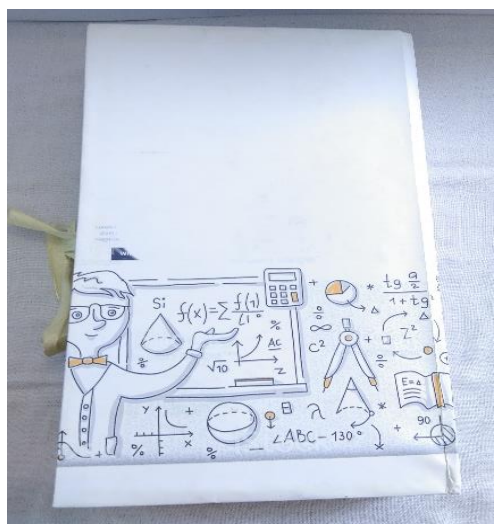

Halaman Kesembilan Ketika Buku Ditutup

Gambar 3. Isi Pop-Up Book

e) Panduan penggunaan dibuat dilembar kerja software Corel Draw $X 7$ dengan ukuran A5 dan dicetak bolak-balik menggunakan kertas Art Paper dengan ketebalan 150 gram.
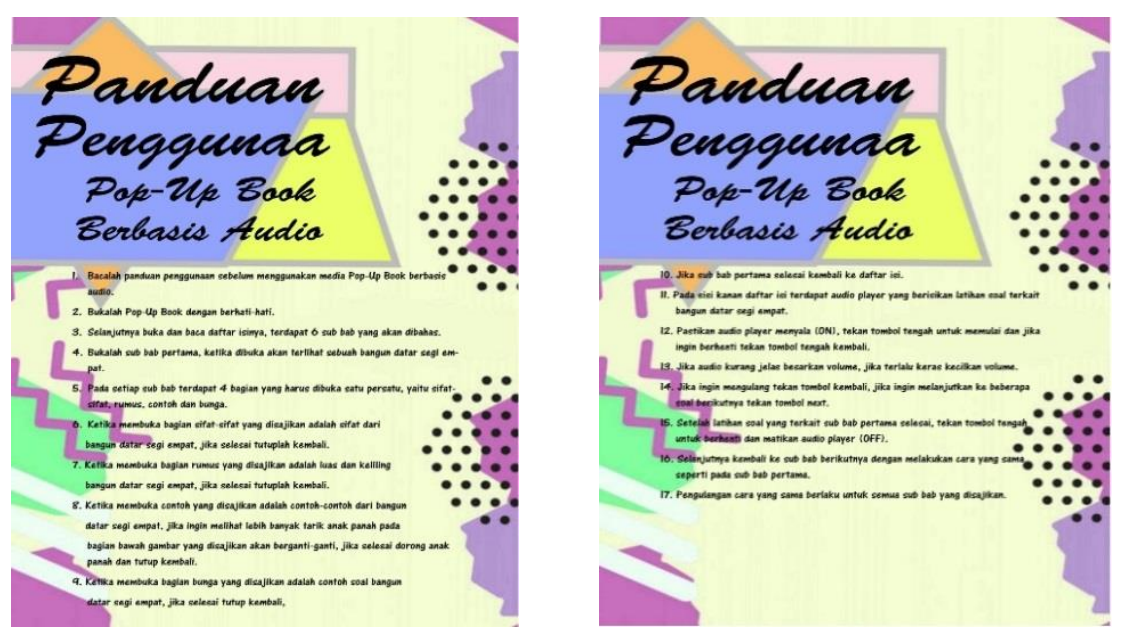

Gambar 4. Panduan Penggunaan 
f) Penyusunan Dubbding yaitu untuk merekem soal-soal yang disampaikan, peneliti dibantu dengan aplikasi "Pengubah Suara". Soal yang di sampaikan sebanyak 30 soal yang terdiri dari 5 soal persegi, 5 soal persegi panjang, 5 soal jajagenjang, 5 soal trapesium, 5 soal layang-layang dan 5 soal belah ketupat.

g) Penyusunan audio (Gambar 5) yaitu ditempel pada halaman kedua disamping daftar isi yang butuhkan untuk penyusunan audio adalah speaker dengan ratio $65 \mathrm{~dB}, \mathrm{mp} 3$, memori, box baterai, 4 baterai dengan size AA LR6 1.5 V, kabel, solasi hitam bolak-balik.

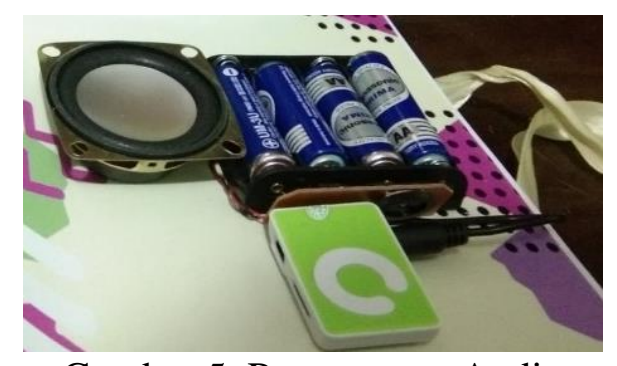

Gambar 5. Penyusunan Audio

4) Validasi Desain

Media pembelajaran Pop-Up

Book berbasis audio pada materi bangun datar di SMP divalidasi oleh 2 validator. Kedua validator yaitu validator ahli merupakan dosen Pendidikan Matematika Universitas Muhammadiyah Malang dan praktisi pembelajaran merupakan guru matematika kelas VII di SMP Islam Ma'arif 03 Malang. Hasil penilaian oleh kedua validator yaitu aspek tampilan memperoleh rata-rata persentase $95 \%$, aspek audio $81,25 \%$, aspek bahasa $87,5 \%$, aspek layout $83,3 \%$ dan aspek isi 93,75\%. Dari keempat aspek tersebut memperoleh ratarata sebesar $88,16 \%$ berkategori sangat valid dengan keterangan layak digunakan. Dengan beberapa saran yang diberikan oleh validator untuk diperbaiki.

\section{5) Revisi Desain}

Setelah memasuki tahap validasi terdapat beberapa revisi yang telah disampaikan validator melalui kolom komentar dan saran yang ada dilembar validasi media. Kesalahan penulisaan "Penggunaa" yang seharusnya "Penggunaan". Kesalahan tata letak contoh bangun datar yang disajikan, seharusnya bangun yang ada keterangan sisi, alas, tinggi dan seterusnya ditaruh dibagian depan.

6) Uji Coba Produk

Pop-Up Book berbasis audio yang telah divalidasi dan diperbaiki serta dinyatakan layak oleh ahli media dan praktisi kemudian di uji coba kan kepada siwa SMP Islam Ma'arif 03 Malang kelas VII. Uji coba produk ini dilakukan oleh 6 siswa kelas VII dan dipilih secara acak yaitu 3 siswa perempuan dan 3 siswa laki-laki. Pop-Up Book berbasis audio diberikan pada kelompok kecil yang berjumlah 6 siswa. Selama uji coba media berlangsung seorang observer menilai aktivitas siswa meggunakan media tersebut. Setiap setelah itu siswa diminta untuk mengerjakan latihan soal yang terdapat pada audio soal secara berkelompok, setelah itu dikoreksi bersama-sama. Pada bagian akhir pembelajaran siswa diberikan tes dan angket respon.

Hasil yang diperoleh pada uji coba produk ini adalah aktivitas siswa memiliki rata-rata persentasenya adalah $92 \%$ dengan 
DOI: https://doi.org/10.24127/ajpm.v8i1.1951

kriteria sangat baik, angket respon siswa memiliki rata-rata persentasenya adalah $88,1 \%$ dengan kriteria sangat baik dan untuk hasil belajar siswa memiliki rata-rata persentase ketuntasan klasikalnya 100\% dengan KKM 75.

7) Revisi Produk

$$
\text { Perlu menggunakan }
$$
tambahan speaker ratio $100 \mathrm{~dB}$ agar memperkeras audio soal, jika di uji coba kan pada kelompok besar. Banyak mendapat komentar positif mengenai media Pop-Up Book berbasis audio.

\section{8) Uji Coba Pemakaian}

Pop-Up Book berbasis audio yang telah divalidasi dan diperbaiki serta dinyatakan layak oleh ahli media dan praktisi kemudian di uji coba kan kepada siwa SMP Islam Ma'arif 03 Malang kelas VII. Uji coba pemakaian ini dilakukan oleh 25 siswa kelas VII. Pop-Up Book berbasis audio diberikan pada setiap kelompok yang beranggota 5 siswa. Selama uji coba media berlangsung seorang observer menilai aktivitas siswa meggunakan media tersebut. Setiap setelah itu siswa diminta untuk mengerjakan latihan soal yang terdapat pada audio soal secara berkelompok, setelah itu dikoreksi bersama-sama. Pada bagian akhir pembelajaran siswa diberikan tes dan angket respon.

Hasil yang diperoleh pada uji coba produk ini adalah aktivitas siswa memiliki rata-rata persentasenya adalah $86,8 \%$ dengan kriteria sangat baik, angket respon siswa memiliki rata-rata persentasenya adalah 88,87 \% dengan kriteria sangat baik dan untuk hasil belajar siswa memiliki rata-rata persentase ketuntasan klasikalnya 92\% dengan KKM 75.

9) Revisi Produk

Tidak terdapat revisi setelah dilakukan uji coba pemakaian kelompok besar pada siswa kelas VII yang berjumlah 25 siswa di SMP Islam Ma'arif 03 Malang.

Berdasarkan hasil penelitian yang telah dilakukan, media pembelajaran Pop-Up Book berbasis audio pada materi bangun datar segiempat di SMP telah dikembangkan sesuai dengan sembilan tahap yaitu potensi masalah, pengumpulan informasi, desain produk, validasi desain, revisi desain, uji coba produk, revisi produk, uji coba pemakaian, revisi produk. Kevalidan media dinilai berdasarkan analisis data lembar validasi media, yang didalamnya terdapat aspek tampilan, aspek audio, aspek bahasa, aspek layout dan aspek isi. Hasil validasi media pembelajaran Pop-Up Book berbasis audio berkriteria sangat valid maka media Pop-Up Book berbasis audio layak untuk diuji cobakan dalam pembelajaran bangun datar segiempat.

Media pembelajaran yang telah dibuat dan telah divalidasi kemudian diuji cobakan untuk melihat keefektifannya dengan melakukan 2 kali uji coba pada siswa kelas VII. Pertama adalah angket respon siswa yang dinilai berdasarkan aspek isi, aspek tampilan dan aspek audio. Hasil analisis data respon siswa pada uji coba 1 maupun uji coba 2 dinyatakan sangat baik. Kedua adalah aktivitas siswa yang dinilai berdasarkan aspek visual, aspek menulis, aspek menggambar, aspek 
emosional dan aspek mental. Hasil analisis data aktivitas siswa pada uji coba 1 maupun uji coba 2 dinyatakan sangat baik. Ketiga adalah hasil belajar siswa yang dinilai berdasarkan soal yang diberikan setelah menggunakan media Pop-Up Book berbasis audio harus memenuhi kriteria ketuntasan minimum (KKM) yaitu 75. Hasil analisis persentase ketuntasan klasikal siswa pada uji coba 1 maupun uji coba 2 dinyatakan $\geq$ $75 \%$. Dapat disimpulkan bahwa media Pop-Up Book berbasis audio dikatakan efektif digunakan sebagai media pembelajaran pada materi bangun datar segiempat.

Hal ini sejalan dengan penelitian Dewanti (2018) dan Safri, Sari \& Marlina (2017) menyatakan kelayakan media dilihat dari hasil validasi keseluruhan secara berturut-turut yaitu 95,20\% dan 92,67\% dengan kriteria sangat valid, maka media layak untuk digunakan dalam pembelajaran. Azizan (2017) dan Kharisma (2017) menyatakan hasil angket repon, aktivitas siswa dan hasil belajar secara berturut-turut. Angket respon yang memiliki ratarata pesentase $98 \%$ dan $92 \%$ dengan kategori sangat baik, aktivitas siswa dikelas memiliki rata-rata persentase $88,8 \%$ dan 97 $\%$ dengan kategori sangat baik sedangkan hasil belajar siswa memiliki rata-rata persentase ketuntasan klasikal $82 \%$ dan $87 \%$ dengan kategori sangat baik. Yang artinya media Pop-Up Book efektif gunakan sebagai media pembelajaran. Vate (2012) melakukan 2 kali uji coba dengan memberikan tes, tes pertama memperoleh $87,78 \%$ dan tes kedua memperoleh $87,4 \%$.

\section{KESIMPULAN DAN SARAN}

Proses pengembangan media PopUp Book berbasis audio pada materi bangun datar segiempat melalui 9 tahapan. Dalam pembuatannya menggunakan software Corel Draw X7. Hasil validasi dari ahli media dan praktisi pembelajaran rata-rata persentasenya adalah $88,16 \%$ dengan kriteria sangat valid yang artinya media Pop-Up Book berbasis audio layak digunakan sebagai media pembelajaran pada materi bangun datar segiempat. Media juga dikatakan efektif karena respon siswa dan aktivitas belajar sangat baik serta hasil belajar siswa yang diukur dengan persentase ketuntasan klasikal sebesar $87 \%$ lebih. Media ini dapat dijadikan alternatif oleh guru dalam pembelajaran materi segiempat.

Pada pengembangan media ini belum sampai pada tahapan diseminasi produk. Oleh karena produk ini valid dan efektif untuk digunakan, maka perlu kiranya ada pihak-pihak yang dapat memproduksi media ini secara masal sehingga dapat digunakan pada sekolah lainnya. Selain itu untuk penelitian selanjutnya dapat mengembangkan media serupa pada materi bangun datar yang lainnya.

\section{DAFTAR PUSTAKA}

Ahmadi, F., Fakhruddin., Trimurti, \& Khasanah, K. (2017). The Development Of Pop-Up Book Media To Improve 4th Grade Students' Learning Outcomes Of Civic Education. 3rd International Conference On Theory \& Practice. 978-0-9953980-5-4. Universitas Negeri Semarang.

Arikunto, S. (2013). Prosedur Penelitian : Suatu Pendekatan Praktik. Jakarta: PT. Rineka Cipta. 
DOI: https://doi.org/10.24127/ajpm.v8i1.1951

Azizan, Y. (2017). Pengembangan Pop Up Book Dalam Pembelajaran Menulis Puisi Berbasis Psychowriting Pada Siswa Kelas VIII D SMP Negeri 1 Srengat Kabupaten Blitar. Skripsi. Surabaya: Universitas Negeri Surabaya.

Cahyadi, D. (2014). Pengembangan Media Pembelajaran Berbasis Flash Pada Mata Pelajaran IPA Terpadu Pokok Bahasan Wujud Zat Dan Perubahannya Kelas VII SMPN 5 Satu Atap Bumijawa. Skripsi. Semarang: Universitas Negeri Semarang.

Cahyani, A. N. (2014). Pengembangan Modul Berbasis Pop-Up Book Pada Materi Alat-Alat Optik Untuk Siswa SMPLB-B (Tunarungu) Kelas VIII. Skripsi. Yogyakarta: UIN Sunan Kalijaga.

Cintas, J.D. \& Remael, A. (2014). Audio-Visual Translation. SysMedia. WinCaps : Routledge.

Dewanti, H. (2018). Pengembangan Media Pop Up Book Untuk Pembelajaran Lingkungan Tempat Tinggalku Kelas IV SDN 1 Pakunden Kabupaten Ponorogo. Skripsi. Malang : Universitas Negeri Malang.

Gurganus. (2010). Characteristics of student's mathematics learning. www.education.com/reference/art icle/students-math-learningproblems/.

Haryoko, S. (2012). Efektifitas Pemanfaatan Media Audio-Visual Sebagai Alternatif Optimalisasi Model Pembelajaran. Makasar. Universitas Negeri Makasar. Jurnal Edukasi Elektro, 5(1), 1 10.

Husain, N. (2017). Pengembangan Media Pembelajaran Berbasis Audio Visual Pada Materi Pencemaran Lingkungan Kelas
Vii Smp Negeri 6 Duampanua Kabupaten Pinrang. Skripsi Makasar: Universitas Islam Negeri (UIN) Alauddin Makassar. Kharisma, M. (2017). Pengembangan Media Pembelajaran Pop Up Book Untuk Meningkatkan Hasil Belajar Siswa Pada Materi Minyak Bumi Dan Petrokimia Di Kelas XI MAS MUTA'ALLIMIN Aceh Besar. Skripsi. Banda Aceh : Universitas Islam Negeri ARRanry.

Musfiqon. (2012). Pengembangan Media \& Sumber Pembelajaran. Jakarta: PT. Prestasi Pustakaraya.

Mustakim. (2016). Peningkatan Hasil Belajar Matematika Materi Bangun Datar Segiempat Melalui Model Pembelajaran ELPSA Dengan Permainan KSD Bagi Siswa Kelas VII A SMPN 2 Patean Kendal Semester 2 Tahun Pelajaran 2015/2016. Jurnal Pendidikan, 17(1), 22 - 44.

Okamura, S. \& Igarashi, T. (2010). An Assistant Interface to Design and Produce a Pop-Up Card. International Journal of Creative Interfaces and Computer, 1(2), 40 -50 .

Pamuji, T., Budiyono, \& Yuzianah, D. (2014). Persepsi Terhadap Mata Pelajaran Matematika Siswa SMP Kelas VIII. Jurnal EKUIVALEN. 12(4).

Rahayu, S. (2016). Analisis Kesalahan Siswa dalam Menyelesaikan Soalsoal Kesebangunan. Jurnal eDuMath, 2(1), $1-9$.

Riyana, C. (2012). Media Pembelajaran. Jakarta : Direktorat Jendral Pendidikan Islam, Kementrian Agama RI.

Safri, M., Sari, S.A., \& Marlina. (2017). Pengembangan Media Belajar PopUp Book Pada Materi Minyak Bumi. Jurnal Pendidikan Sains Indonesia, 5(1), 107 - 113. 
DOI: https://doi.org/10.24127/ajpm.v8i1.1951

Sardiman, A.M. (2011). Interaksi dan Motivasi Belajar Mengajar. Jakarta: PT RajaGrafindo Persada.

Devi, S.A., \& Maisaroh, S. (2017). Pengembangan Buku Pop-Up Wayang Tokoh Pandhawa Pada Mata Pelajaran Bahasa Jawa Kelas V SD. Jurnal PGSD Indonesia. 3(2).

Sugiyono. (2015). Metode Penelitian : Kuantitatif, Kualitatif, dan $R \& D$. Bandung : Alfabeta.

Susilana, R. \& Riyana, C. (2009). Media Pembelajaran. Bandung : CV. Wacana Prima.

Vate, Poonsri. (2012). An Augmented Reality 3D Pop-Up Book: the Development of a Multimedia Project for English Language Teaching. IEEE International Conference on Multimedia and Expo, $890-895$.

Wiana, W. (2017). Interractive MultimediaBased Animation: A Study Of Effectiveness On Fashion Design Technology Learning. The 2nd International Joint Conference on Science and Technology (IJCST).
Bandung : Indonesia University of Education.

Widalatika, V. N. (2014). Pengembangan Media Visual Kirigami Pop Up Dengan Materi Potensi Dan Sebaran Sumber Daya Alam Indonesia Untuk Pembelajaran IPS Di SMP Kelas VII. Skripsi. Yogyakarta : Universitas Negeri Yogyakarta.

Widodo, S. A., \& Wahyudi. (2018). Selection of Learning Media Mathematics for Junior School Students. TOJET (The Turkish Online Journal of Educational Technology), 17(1), 154-160.

Wirayanti, P.M., Hidayah, I.N., \& Muksar, M. (2016). Pengembangan Lembar Kegiatan Siswa (LKS) Dengan Strategi REACT Pada Materi Keliling Dan Luas Lingkaran. Prosiding Seminar Nasional Pendidikan Matematika: "Strategi Pengembangan Kualitas Pembelajaran Matematika Dalam Kurikulum Nasional “, 359 - 370. Pendidikan Matematika UNISSULA. 